\section{The Science House: A University Science and Math Outreach Program}

The best compliment I ever got about my teaching came from a fifth grade teacher who said she spent two weeks with her students doing all the hands-on activities from my Physics From the Junk Drawer workshop. They did dozens of experiments with paper cups, string, clay, paper clips, and soda straws. At the end of two weeks, the students put on a show-and-tell of their activities for their parents. Before attending our workshop, that teacher, like most elementary school teachers, probably had not lead her students in many such activities. She was probably also a little unsure of her science knowledge. Now, however, I think she understands the excitement of "doing" science in her classroom.

Physics From the Junk Drawer is a workshop offered by The Science House at North Carolina State University (NCSU). The Science House, an outreach program of the physical science and mathematics departments, has the goal of increasing hands-on learning in the sciences. The Science House is also a growing partnership with North Carolina teachers, who participate in, plan, and direct many of the teaching activities. The Science House has teaching classrooms and labs on the NCSU campus and outreach programs that travel over a large part of North Carolina. This is an unusual initiative for a group of departments best known for their undergraduate teaching and their graduate research activities. However, The Science House mission is right in line with the land-grant heritage of NCSU.

At The Science House we work with many teachers of all grade levels to help them use hands-on learning in their classrooms. For elementary and middle school teachers, the programs emphasize doing science and math with things easily avail able at the grocery or hardware store. Teachers who attend Countertop Chemistry, or Digging into Earth Science, or Hands-On Math, leave the workshop with a book of activity plans and boxes of materials to use with their own students. Often the stuff we teach on Tuesday night is used with a class of fourth graders on Wednesday morning.

One especially successful teacher workshop, Countertop Chemistry, was developed and taught by Melissa Brown, a local high school teacher, who worked one year as the co-director of The Science
House. The Countertop Chemistry manual has about 30 experiments suitable for grades four through nine. The experiments, from the three recipes for slime to the thermodynamics of making ice cream, are all proven interest-getters. Because of today's safety and waste disposal concerns, the experiments involve chemicals found at the grocery or hardware store. A section on chemical safety was included with the help of NCSU chemistry faculty. The labs include an explanation of the science, step-by-step instructions, supply lists, and, most important, many teachertested tips for hands-on activities.

Our collaboration with high school teachers has a high-tech focus. A couple of years ago, some of us were discussing how frustrating it is to show teachers new equipment and teaching technologies at a workshop or summer institute, knowing that the teachers will not have access to such equipment at their own schools. Schools in rural areas and small towns are especially lacking in computers and teaching equipment. This frustration led to the development of two programs for rural high school biology, chemistry, and physics teachers. Following some ideas from Juniata College in Pennsylvania, we send two vans of Macintosh computers and Vernier Software computer-based lab probes, plus other equipment, to 15 schools in eastern and southern North Carolina. The teachers who use the equipment have been trained during summer institutes at NCSU and have made a long-term commitment to find the best ways to use these teaching technologies with their students.

Two Master Teachers from NCSU drive the vans and assist with teaching classes. The vans and the programs are supported by the National Science Foundation and the Howard Hughes Medical Institute. The programs were developed through the cooperation of faculty from the departments of chem-

The Education Exchange highlights the experiences of scientists and engineers with local schools, along with helpful hints and resources. If you would like to share your own involvement in science education, contact: Finley Shapiro, Department of Electrical and Computer Engineering, Drexel University, Philadelphia, PA 19104, U.S.A. Phone (215) 895-6749; fax (215) 895-1695; e-mail: shapiro@ece.drexel.edu istry, physics, zoology, and math and science education.

What have I learned from our work at The Science House?

First, scientists know science, but teachers know children. We have explained much about science and new teaching technologies, and the teachers have shown us what works and what does not work with their students. Often they bring a new slant to a teaching activity, and some of their ideas are even used in my undergraduate physics classes.

Second, teachers have a lot of initiative and energy, and sometimes we can help bring their ideas to fruition. For instance, the teachers in our rural schools institutes got so excited about teaching with computer-based lab equipment that several of them effectively politicked their principals and superintendents to find money for computers and other equipment. We trained the teachers and they used that training to acquire resources. We did not foresee that result in planning our outreach program.

Third, nothing beats simple hands-on activities. My favorite activity this year is about shoes. One can determine the friction of shoe soles by putting a shoe on a wooden board and slowly lifting one end of the board until the shoe begins to slide. The higher the angle of the board, the greater the friction of the sole. We measured all the shoes in several elementary school classes and compared the friction of different types of shoes (basketball, running, walking), types of soles (rubber, leather), and different brands of shoes. By the end of the exercise, the students were comparing each other's shoes, realizing that science went into their design.... I wonder if Mike tests his shoes that way?

D. HAASE

For more information about The Science House, contact: David Haase, The Science House, Box 8211, North Carolina State University, Raleigh, NC 27695-8202. Phone (919) 515-6118; fax (919) 515-7545; e-mail: David_Haase@NCSU.edu.
David Haase is professor of physics and co-director of The Science House at North Carolina State University. A condensed matter scientist by training, he builds cryo- genic polarized targets for nuclear physics research. The people who do all this stuff are Mike Smith, Todd Boyette, Judy Powell, Melissa Brown, Betty Welsh, Pat Hall, Elizabeth Woolard, Dr. Alton Banks, Dr. John Park, Dr. Charles Lytle, Dr. William Switzer, and Dr. Jerry Whitten. 